\title{
AS UNIDADES ECODINÂMICAS NA ANÁLISE DA FRAGILIDADE AMBIENTAL DO PARQUE ESTADUAL DO MORRO DO DIABO E ENTORNO, TEODORO SAMPAIO/SP
}

\author{
Rosangela do Amaral* \\ Jurandyr Luciano Sanches Ross**
}

\section{RESUMO}

O presente artigo apresenta um estudo de caso desenvolvido em Teodoro Sampaio/SP, no Pontal do Paranapanema, para determinar a fragilidade ambiental a partir da proposta metodológica de ROSS (1994) em "Análise Empírica da Fragilidade dos Ambientes Naturais e Antropizados", utilizando o conceito de Unidades Ecodinâmicas.

O objetivo do estudo da fragilidade ambiental foi avaliar as áreas suscetíveis à degradação para subsidiar ações de planejamento que restrinjam e direcionem o uso e ocupação da terra, de forma a prevenir e minimizar o surgimento de problemas relacionados à qualidade ambiental.

A área de estudo foi selecionada por conter diferentes tipos de uso da terra, com características naturais e antrópicas. Foram levantados dados secundários e desenvolvidos ensaios de campo para a caracterização de quatro fatores primordiais para a análise: uso da terra/cobertura vegetal, relevo, solos e clima.

\section{PALAVRAS-CHAVE}

Fragilidade, Unidades Ecodinâmicas, análise integrada, planejamento ambiental, Parque Estadual do Morro do Diabo

\section{ABSTRACT}

This paper is a case study in the municipality of Teodoro Sampaio, Pontal do Paranapanema, to determine the environmental fragility, developed from the methodological proposal by ROSS (1994) in "Empirical analysis of the fragility of natural and humanized environments" (Análise empírica da Fragilidade dos Ambientes Naturais e Antropizados), using the Ecodynamical Units concept.

The objective of this environmental fragility study is to evaluate degradation susceptive areas to subsidize planning actions that restrict and direct land use. These actions are planned to prevent and minimize the appearance of problems related to environmental quality.

The study area was selected because it contains different forms of land use, with natural and anthropic characteristics. Secondary data was obtained from previous studies and field surveys were carried out to characterize four important factors for the final analysis: land use/vegetal cover, relief, soil and climate.

\section{KEY WORDS}

Fragility, Ecodynamical Units, integrated analysis, environmental planning, Morro do Diabo State Park / São Paulo / Brazil

\footnotetext{
* Pesquisadora Científica, Chefe da Seção de Geografia Aplicada do Instituto Geológico - Secretaria do Meio Ambiente do Estado de São Paulo e Mestre em Geografia Física pelo Departamento de Geografia - FFLCH - USP. E-mail: rosangela.amaral@igeologico.sp.gov.br

** Professor Titular do Departamento de Geografia - FFLCH - USP. E-mail: juraross@usp.br
} 


\section{Introdução}

A proposta metodológica de ROSS (1994) em "Análise Empírica da Fragilidade dos Ambientes Naturais e Antropizados", foi desenvolvida com base nas concepções de Ecodinâmica e Ecossistema, definidas em trabalhos anteriores de TRICART (1977). Neste estudo de caso em Teodoro Sampaio/SP, no Pontal do Paranapanema, foi aplicado o conceito de Unidades Ecodinâmicas para determinar a fragilidade ambiental.

Sob essa concepção metodológica o ambiente é analisado segundo a Teoria dos Sistemas, que parte do pressuposto de que na natureza os fluxos de energia e matéria se processam por meio de relações em equilíbrio dinâmico, ou seja, a evolução natural dos componentes do ambiente se dá em harmonia entre si.

No entanto, a ação antrópica na natureza afeta a funcionalidade do sistema e induz aos processos degenerativos. Normalmente, buscase o retorno técnico e econômico imediato, sem prognosticar as consequências passíveis de ocorrer em longo prazo devido a essas intervenções. Com base nesses fatos acredita-se que todo planejamento deva considerar as potencialidades dos recursos naturais, mas, sobretudo, as fragilidades diante das diferentes intervenções antrópicas na natureza.

O Pontal do Paranapanema, localizado no Oeste do Estado, é uma área que foi vastamente modificada, hoje caracterizada por pastagens extensivas em relevo de colinas amplas, apresentando intensos processos erosivos.

A área de estudo (Figura 1) tem como características relevantes a presença de uma Unidade de Conservação, o Parque Estadual do Morro do Diabo, e em seu entorno assentamentos rurais com cultivos diversificados, onde são evidenciadas marcas de processos erosivos.

\section{Objetivo}

O estudo da fragilidade ambiental teve como objetivo avaliar as áreas suscetíveis à degradação para subsidiar ações de planejamento que restrinjam e direcionem o uso e ocupação da terra, de forma a prevenir e minimizar o surgimento de problemas relacionados à qualidade ambiental.

Para a aplicação do conceito de Unidades Ecodinâmicas foram analisados integradamente dados de uso da terra (componente antrópica) e de relevo, solos e clima (componentes ambientais), em escala 1:50.000. Foram definidas as Unidades Ecodinâmicas de Instabilidade Emergente para áreas antropizadas e de Instabilidade Potencial para áreas naturais, com graus de fragilidade variando de muito baixo a muito alto.

\section{Proposição Metodológica}

Para avaliar a área de estudo foi utilizada a proposta metodológica de ROSS (1994), em que se utiliza o conceito de Unidades Ecodinâmicas de Instabilidade Potencial e de Instabilidade Emergente, classificadas em graus de fragilidade. Essa proposta foi desenvolvida com base na concepção de Ecodinâmica definida por TRICART (1977) e ambas foram relacionadas conforme Quadro 1.

Ambas as metodologias têm como objetivo proceder a análises integradas dos dados, resultados de combinações dinâmicas de elementos físicos, biológicos e antrópicos que fazem da paisagem um conjunto único e indissociável, sempre em evolução (BERTRAND, 1971). Outras formas de análises integradas podem ser vistas, por exemplo, nas concepções de Geossistema, exploradas por diversos autores (BERTRAND， 1971， SOTCHAVA， 1978 e MONTEIRO, 2000). 
Figura 1 - Localização da Área de Estudo na Imagem de Satélite Landsat de 1997
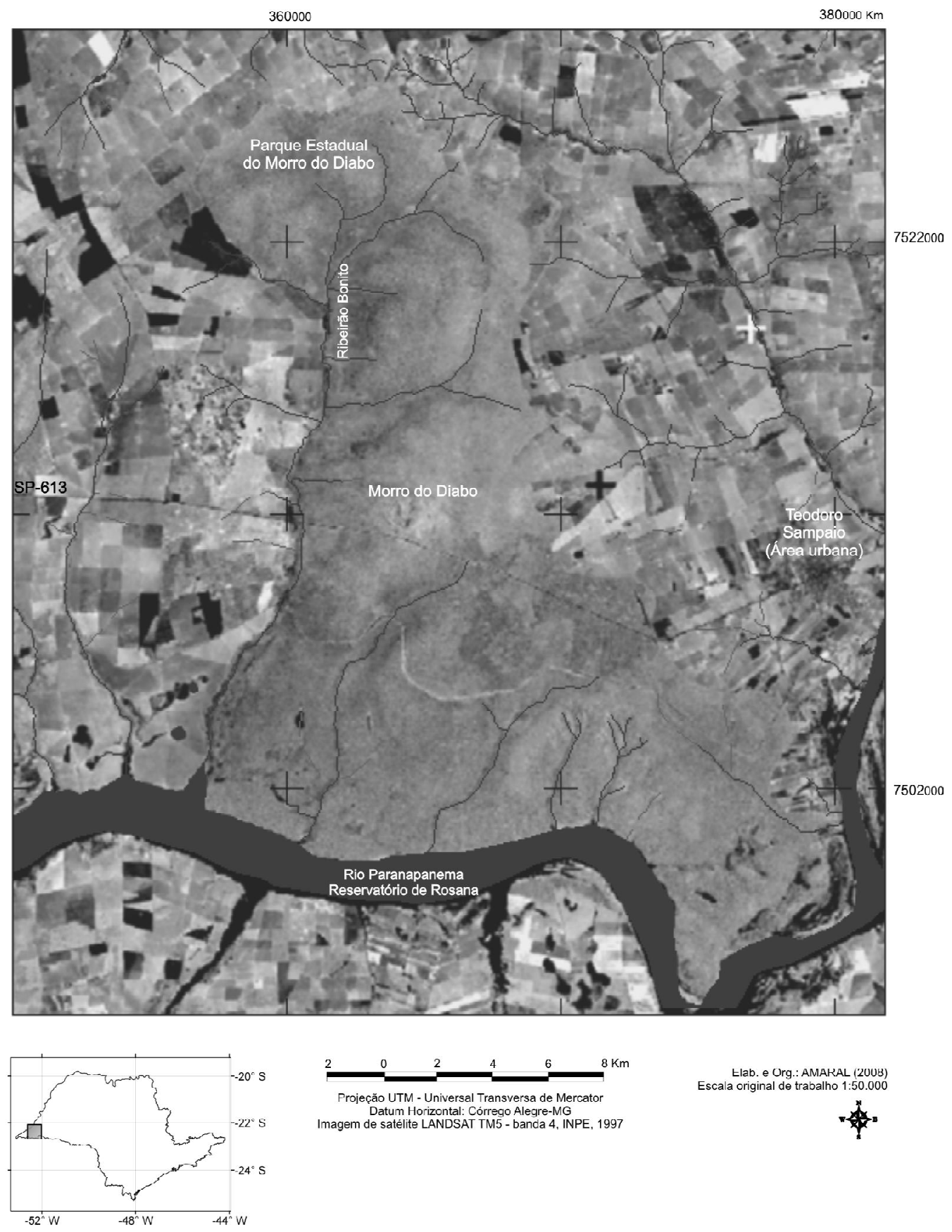
Elab. e Urg.: AMARAL (2008)
Escala original de trabalho 1:50.000 Imagem de satélite LANDSAT TM5 - banda 4, INPE, 1997 年" 


\section{Quadro 1 - Relação entre os conceitos relacionados aos ambientes naturais e antropizados definidos por ROSS (1994) e TRICART (1977).}

\begin{tabular}{|l|l|l|l|}
\hline \multirow{2}{*}{ Autores } & \multirow{2}{*}{$\begin{array}{c}\text { Proposta } \\
\text { metodológica }\end{array}$} & \multicolumn{2}{c|}{ Conceitua o } \\
\cline { 3 - 4 } & Ecodinâmica & Unidades Estáveis & Anbientes antropizados \\
\hline TRICART, 1977 & Unides Instáveis \\
\hline ROSS, 1994 & $\begin{array}{l}\text { Fragilidade } \\
\text { ambiental }\end{array}$ & $\begin{array}{l}\text { Unidades Ecodinâmicas de } \\
\text { Instabilidade Potencial }\end{array}$ & $\begin{array}{l}\text { Unidades Ecodinâmicas de } \\
\text { Instabilidade Emergente }\end{array}$ \\
\hline
\end{tabular}

Org.: AMARAL (2008).

As Unidades Ecodinâmicas de Instabilidade Potencial (Estáveis) são as que estão em equilíbrio dinâmico em seu estado natural, porém, há uma instabilidade potencial contida nelas diante da possibilidade da intervenção antrópica.

As Unidades Ecodinâmicas de Instabilidade Emergente (Instáveis) foram definidas como os ambientes naturais que foram modificados intensamente pelo homem com desmatamentos, agriculturas, industrialização e urbanização, portanto, denominados ambientes antropizados.

Para se obter a classificação das unidades ecodinâmicas é necessário proceder a levantamentos de dados sobre o uso da terra (componente antrópica) e de relevo, solos e clima (componentes ambientais), que se constituirão fatores determinantes dos graus de fragilidade ambiental. Os fatores e os respectivos elementos que os compõem, considerados nesta análise, são dispostos no Quadro 2.

\section{Quadro 2 - Fatores e elementos de análise para determinação da fragilidade ambiental.}

\begin{tabular}{|l|l|}
\hline \multicolumn{1}{|c|}{$\begin{array}{c}\text { Fatores de análise para } \\
\text { fragilidade ambiental }\end{array}$} & \multicolumn{1}{|c|}{ Elementos } \\
\hline Uso da Terra/Cobertura vegetal & $\begin{array}{l}\text { Densidade da cobertura vegetal. } \\
\text { Presença de práticas conservacionistas. }\end{array}$ \\
\hline Relevo & $\begin{array}{l}\text { Tipos de vertentes. } \\
\text { Índices de declividade. }\end{array}$ \\
\hline Solos & $\begin{array}{l}\text { Textura (análise granulométrica). } \\
\text { Profundidade / espessura dos horizontes superficiais e } \\
\text { subsuperficiais. } \\
\text { Permeabilidade / Compactação. }\end{array}$ \\
\hline Clima & Distribuição anual e intensidade da pluviometria. \\
\hline
\end{tabular}

Org.: AMARAL (2008)

Cada um dos fatores analisados deve ser hierarquizado em graus de fragilidade, que variam entre muito baixo, baixo, médio, alto e muito alto. A composição final do grau de fragilidade é a associação dos quatro fatores analisados, em que o fator uso da terra/cobertura vegetal é preponderante para determinar a classificação da Unidade Ecodinâmica.

Deste modo, a associação numérica representa um dígito para o grau de proteção aos solos pela vegetação (natural ou cultivada), variando da mais protetora a menos protetora, 
outro para a intensidade de dissecação do relevo ou declividade, outro para a suscetibilidade à erosão dos tipos de solos, do menos suscetível ao mais suscetível, e, finalmente, o quarto dígito, referente aos tipos de comportamento pluviométrico.

A análise integrada dos fatores dará origem à carta-síntese (Carta das Unidades Ecodinâmicas de Instabilidade Potencial e Emergente).

\section{Discussão e Resultados}

Na área de estudo, para se obter a classificação das unidades, foi efetuado o levantamento e avaliação dos quatro fatores, em escala 1:50.000, de acordo com os parâmetros determinados na proposta de ROSS (1994): Uso da Terra/Cobertura Vegetal, Relevo, Solos e Clima. Posteriormente, esses fatores foram analisados integradamente.
1) Uso e ocupação da terra e cobertura vegetal.

O primeiro fator avaliado, preponderante para a determinação da classificação da Unidade Ecodinâmica, é o uso e ocupação da terra, e se refere ao grau de proteção ao solo, de acordo com a cobertura vegetal predominante.

O estudo foi feito a partir de interpretação da imagem de satélite Landsat TM5, órbita/ponto 222/75, 222/76, 223/75 e 223/76, composição colorida RGB, de 1997 (SMA, 1999), complementado com levantamentos de campo em locais específicos para subsidiar a elaboração da Carta de Uso da Terra.

A imagem de satélite foi tratada no software Spring e classificada pelo método supervisionado Maxver (máxima verossimilhança).

A classificação final do fator uso da terra é representada no Quadro 3.

\section{Quadro 3 - Graus de proteção do solo na área de estudo de acordo com o uso da terra}

\begin{tabular}{|c|c|}
\hline Graus de Proteção & $\begin{array}{c}\text { Tipos de Uso da Terra / Cobertura vegetal } \\
\text { (Ocorrências na área de estudo) }\end{array}$ \\
\hline 1- Muito Alto & Florestas/Matas natura is \\
\hline 2- Alto & Capoeira \\
\hline 3- Médio & (sem ocorrências) \\
\hline 4- Baixo & $\begin{array}{l}\text { Pastagem sem práticas conservacionistas } \\
\text { Agriculturas diversas sem práticas conservacionistas }\end{array}$ \\
\hline 5- Muito baixo a nulo & $\begin{array}{l}\text { Áreas desmatadas e queimadas recentemente } \\
\text { Solo exposto por arado/gradeação } \\
\text { Solo exposto ao longo de caminhos e estradas }\end{array}$ \\
\hline
\end{tabular}

Fonte: AMARAL (2005).

2) Relevo.

Para avaliar o fator relevo e elaborar a Carta Geomorfológica da área de estudo foi feita uma compartimentação por tipos de vertentes, utilizando-se a classificação taxonômica proposta por ROSS (1992), em que se detalhou a análise das formas de relevo presentes entre o $4^{\circ}$ e $06^{\circ}$ táxons, respectivamente, tipos de formas de relevo, tipos de vertentes e formas de processos atuais, de acordo com a escala adotada para o levantamento (1:50.000).

A declividade foi associada à compartimentação geomorfológica para auxiliar na hierarquização do grau de fragilidade. Com base nos dados da imagem de satélite, levantamentos secundários e trabalhos de campo, 
foram representadas as formas de processos erosivos atuais: erosão laminar, voçorocas, ravinas e cabeceiras de drenagem com erosão acelerada.

A caracterização regional da área de estudo apresenta o predomínio de formas de relevo denudacionais, com modelado de colinas amplas e baixas com topos convexos e topos planos e tabulares (ROSS \& MOROZ, 1997).

A classificação final do fator relevo é representada no Quadro 4.

\section{Quadro 4 - Classes de fragilidade de acordo com os tipos de vertentes e declividades na área de estudo}

\begin{tabular}{|l|l|}
\hline \multicolumn{1}{|c|}{ Graus de Fragilidade } & \multicolumn{1}{c|}{$\begin{array}{c}\text { Tipos de Vertentes e declividades } \\
\text { (O corrências na Área de Estudo) }\end{array}$} \\
\hline 1- Muito Baixo & Tp - Topos planos (0 a 3\% de declividade) \\
\hline 2- Baixo & $\begin{array}{l}\text { Tc - Topos convexos (0 a 12\% de declividade) } \\
\text { Vc1 - Vertentes convexas (3 a 12\% de declividade) } \\
\text { Pt - Patamares planos (3 a } 12 \% \text { de declividade) }\end{array}$ \\
\hline 3- Médio & $\begin{array}{l}\text { Vcc - Vertentes côncavas (3 a 12\% de declividade) } \\
\text { Vc2 - Vertentes convexas com declividades médias } \\
(12 \text { a 30\%) }\end{array}$ \\
\hline 4- Alto & $\begin{array}{l}\text { Vr2 - Vertentes retilíneas com declividades médias } \\
(12 \text { a 30\% de declividade) }\end{array}$ \\
\hline 5- Muito Alto & $\begin{array}{l}\text { Vr1 - Vertentes retilíneas com altas declividades } \\
\text { (maiores que 30\% ) } \\
\text { Planície Fluvial (0 a 3\% de declividade) }\end{array}$ \\
\hline
\end{tabular}

Fonte: AMARAL (2005).

3) Solos.

Para avaliar o fator solos e elaborar a caracterização pedológica, foi feita uma análise com base no Mapa Pedológico do Estado de São Paulo (OLIVEIRA et al, 1999) e amostragens de campo, por falta de dados secundários de detalhe da região.

A influência do substrato rochoso no desenvolvimento pedológico é verificada fundamentalmente por meio da composição mineralógica e da permeabilidade. Essa influência é observada tanto nos processos de alteração física e química dos constituintes minerais como nos processos de movimento da matéria no solo.

No caso da área de estudo, o substrato pedogenético, produto da alteração de arenitos não calcíferos apresenta-se relativamente pobre em cátions básicos, facilitando o desenvolvimento de perfis latossólicos. A ocorrência de Argissolos está provavelmente condicionada a coluvionamentos subsuperficiais de areias e argilas transportadas por ação de chuvas torrenciais e movimentação por gravidade ao longo das vertentes mais inclinadas.

As características climáticas favoreceram o desenvolvimento de processos de alteração ferralítica, bem desenvolvidos nos solos da região. A água também exerce papel de fundamental importância, podendo acelerar o processo de migração de argila para os horizontes mais profundos, causando a lixiviação dos sais solúveis. As formas do relevo contribuem para a definição das intensidades destes processos (IPT, 1987).

Em estudos de detalhe, mais importante do que enquadrar o solo em tipos específicos, é 
verificar o seu padrão textural e comportamento hídrico. Em locais antropizados é relevante averiguar o comportamento perante as intervenções que já foram feitas no local, como por exemplo, o uso de maquinários para preparar o solo para o plantio, que causa uma compactação dos horizontes superficiais e, consequentemente, muda os padrões de permeabilidade.

Para estimar essas diferenças, foram escolhidos pontos em locais limítrofes ao Parque (com cobertura de vegetação densa) e em áreas de assentamento rural (culturas diversas).

No total foram efetuados 9 pontos de coleta de solos para análise granulométrica, distribuídos ao longo da principal bacia de drenagem da área de estudo, a bacia do Ribeirão Bonito. Foram amostrados pontos em montante, médio curso e jusante, e em alta, média e baixa vertentes. A análise granulométrica revelou a predominância da fração areia, especialmente médias a finas.

Os solos predominantemente arenosos têm como principal característica uma rápida e profunda infiltração da água, que leva consigo os minerais e empobrece o solo superficial.

Além da análise granulométrica, aplicouse mais algumas técnicas para constatar a permeabilidade do solo em 6 pontos (alta, média e baixa vertentes): testes com infiltrômetros de superfície e subsuperfície e com os penetrômetros de bolso e de percussão (impacto). O Quadro 5 apresenta uma síntese das características dos pontos amostrados, e sua localização pode ser visualizada na Figura 2.

\section{Quadro 5 - Características dos pontos amostrados em campo e resultados da aplicação dos testes com infiltrômetro de subsuperfície e com o penetrômetro de percussão (impacto).}

\begin{tabular}{|c|c|c|c|c|c|c|c|}
\hline \multirow[t]{2}{*}{$\begin{array}{l}\text { Pontos } \\
\text { amostra- } \\
\text { dos }\end{array}$} & \multirow[t]{2}{*}{$\begin{array}{l}\text { Posição no relevo } \\
\text { / Tipo de vertente }\end{array}$} & \multirow[t]{2}{*}{$\begin{array}{l}\text { Cobertura } \\
\text { vegetal / } \\
\text { uso da terra }\end{array}$} & \multirow[t]{2}{*}{$\begin{array}{l}\text { Granulo- } \\
\text { metria }\end{array}$} & \multicolumn{2}{|c|}{$\begin{array}{l}\text { Penetrômetro } \\
\text { de percussão) } \\
\left(\mathrm{kgf} / \mathrm{cm}^{2}\right)\end{array}$} & \multicolumn{2}{|c|}{$\begin{array}{l}\text { Infiltrômetro } \\
\text { de } \\
\text { subsuperfície } \\
(\mathrm{ml} / \mathrm{s})\end{array}$} \\
\hline & & & & $\begin{array}{l}\text { Perío do } \\
\text { chuvoso }\end{array}$ & $\begin{array}{l}\text { Período } \\
\text { se co }\end{array}$ & $\begin{array}{c}\text { Período } \\
\text { chuvo so }\end{array}$ & $\begin{array}{l}\text { Período } \\
\text { seco }\end{array}$ \\
\hline $\mathrm{P}-1$ & $\begin{array}{l}\text { Alta vertente / } \\
\text { vertente convexa } \\
\text { de baixa declividade }\end{array}$ & Floresta & $\begin{array}{l}86 \% \text { areia } \\
4 \% \text { silte } \\
10 \% \text { argila }\end{array}$ & 12,49 & 22,73 & 248 & 592 \\
\hline$P-2$ & $\begin{array}{l}\text { Média vertente / } \\
\text { vertente convexa } \\
\text { de baixa declividade }\end{array}$ & Floresta & $\begin{array}{l}82 \% \text { areia } \\
6 \% \text { silte } \\
12 \% \text { argila }\end{array}$ & 18,72 & 26,93 & 39 & 191 \\
\hline$P-3$ & $\begin{array}{l}\text { Baixa vertente / } \\
\text { planície aluvial }\end{array}$ & Floresta & $\begin{array}{l}82 \% \text { areia } \\
4 \% \text { silte } \\
14 \% \text { argila }\end{array}$ & 12,16 & 16,76 & 9 & 161 \\
\hline$A-1$ & $\begin{array}{l}\text { Alta vertente / topo } \\
\text { convexo de baixa } \\
\text { declividade }\end{array}$ & $\begin{array}{l}\text { Pastagem / } \\
\text { Agricultura }\end{array}$ & $\begin{array}{l}62 \% \text { areia } \\
4 \% \text { silte } \\
34 \% \text { argila }\end{array}$ & 18,39 & 35,78 & 0,7 & 16 \\
\hline$A-2$ & $\begin{array}{l}\text { Média vertente / } \\
\text { vertente côncava } \\
\text { de baixa declividade }\end{array}$ & $\begin{array}{l}\text { Pastagem / } \\
\text { Agricultura }\end{array}$ & $\begin{array}{l}78 \% \text { areia } \\
2 \% \text { silte } \\
20 \% \text { argila }\end{array}$ & 18,73 & 34,15 & 2 & 18 \\
\hline$A-3$ & $\begin{array}{l}\text { Baixa vertente / } \\
\text { vertente convexa } \\
\text { de baixa declividade }\end{array}$ & Pastagem & $\begin{array}{l}74 \% \text { areia } \\
4 \% \text { silte } \\
22 \% \text { argila }\end{array}$ & 25,29 & 53,83 & 2 & 9 \\
\hline
\end{tabular}

Org: AMARAL (2008). 
Os testes com infiltrômetro foram realizados com a finalidade de medir a quantidade e a velocidade de infiltração da água no solo. Um dos testes foi feito com infiltrômetro de superfície, considerando a influência da vegetação e raízes presentes em cada local e as características dos horizontes $\mathrm{A}$ e $\mathrm{O}$. O outro teste foi executado com o infiltrômetro de subsuperfície, a $70 \mathrm{~cm}$ de profundidade, para averiguar o comportamento da permeabilidade no horizonte $\mathrm{B}$.

Nos pontos amostrados na área interna do Parque (P1, P2 e P3), de textura arenosa (cerca de $80 \%$ areia) os testes com os infiltrômetros demonstraram uma infiltração rápida e não houve saturação do solo. Nos locais amostrados nos assentamentos ( $A 1, A 2$ e $A 3)$, de textura média-arenosa (cerca de $70 \%$ areia), a infiltração foi mais lenta e apenas em 2 dos 6 pontos houve saturação. Em todos os pontos amostrados, as taxas de infiltração foram maiores em superfície, demonstrando não haver camada argilosa significativa no topo do horizonte $B$.

Também verificou-se que as taxas de infiltração em subsuperfície aumentaram consideravelmente do período chuvoso para o seco, demonstrando o ressecamento dos solos arenosos, que não retêm água, mostrando-se extremamente permeáveis, o que diminui a possibilidade de ocorrência de processos erosivos laminares e lineares, como ravinas e voçorocas.

O penetrômetro de bolso foi utilizado para medir a resistência de compressão do solo em superfície. O penetrômetro de percussão, com uma haste de $70 \mathrm{~cm}$ e peso de impacto de $4 \mathrm{~kg}$, foi utilizado nos mesmos pontos, para determinar a variação de resistência de superfície e subsuperfície.

Os testes com os penetrômetros revelaram que a resistência do solo ou índice de cone é maior nos pontos que apresentam textura médio-arenosa e em um ponto de textura arenosa. Outro fator importante é que a resistência do solo ( $\mathrm{n}^{\circ}$ de impactos) aumentou consideravelmente em todos os pontos comparando-se a medição realizada no período de seca (agosto) em relação à medição realizada no período chuvoso (março), em função do maior atrito decorrente da pouca umidade dos solos.

A classificação final do fator solos é representada no Quadro 6.

\section{Quadro 6 - Classes de fragilidade na área de estudo de acordo com os tipos de solos}

\begin{tabular}{|l|l|}
\hline \multicolumn{1}{|c|}{ Graus de Fragilidade } & \multicolumn{1}{c|}{ Tipos de Solos (Ocorrências na Area de Estudo) } \\
\hline 1- Muito Baixo & (sem ocorrências) \\
\hline 2- Baixo & (sem ocorrências) \\
\hline 3- Médio & LVA4 - Latossolo Vermelho-Amarelo (textura média) \\
\hline 4- Alto & PVA13 - Argissolos Vermelho-Amarelo (textura arenosa/média) \\
\hline 5- Muito Alto & $\begin{array}{l}\text { RL8 - Neossolos Litólicos com afloramento de rochas (relevo } \\
\text { escarpado) } \\
\text { RL9 - Neossolos Litólicos com afloramento de rochas (relevo } \\
\text { forte ondulado) } \\
\text { GX9 - Gleissolos Háplicos }\end{array}$ \\
\hline
\end{tabular}

Fonte: AMARAL (2005). 
4) Clima.

O quarto fator considerado foi a análise do comportamento pluviométrico regional, a partir de dados do posto pluviométrico D9014 - Fazenda Rosanela, disponibilizados pelo DAEE (2003), referentes ao período de 1973 a 1992.

Nesta área, segundo dados da SMA (1999), o clima é predominantemente tropicalcontinental, dada à participação dos sistemas atmosféricos do Centro-Oeste.
Em referência à classificação de Köppen, a definição é Cwa - Mesotérmico de Inverno Seco, caracterizado por temperaturas médias anuais ligeiramente inferiores a $22^{\circ} \mathrm{C}$, com chuvas típicas de clima tropical de maior ocorrência no verão.

Não foi possível apurar diferenças de comportamento pluviométrico na área de estudo, e, portanto, foram determinadas as características predominantes na região.

A classificação final do fator clima é representada no Quadro 7.

\section{Quadro 7 - Níveis de comportamento pluviométrico na área de estudo}

\begin{tabular}{|l|l|}
\hline Graus de Fragilidade & Características pluviométricas (Ocorrências na área de estudo) \\
\hline $1-$ Muito baixo & (sem ocorrências) \\
\hline 2 - Baixo & (sem ocorrências) \\
\hline $3-$ Médio & $\begin{array}{l}\text { Situação pluviométrica com distribuição anual desigual, com } \\
\text { períodos secos entre 2 e 3 meses no invemo, e no verão com } \\
\text { maiores intensidades de dezembro a março. Média anual em torno } \\
\text { de 1500 mm/a }\end{array}$ \\
\hline $4-$ Alto & (sem ocorrências) \\
\hline $5-$ Muito Alto & (sem ocorrências) \\
\hline
\end{tabular}

Fonte: AMARAL (2005).

5) Análise Integrada.

A partir da avaliação detalhada de cada um dos 4 fatores, realizou-se a análise integrada dos dados, que foi o objetivo principal do estudo.

Foi feita a classificação numérica dos polígonos, a partir das possíveis combinações entre os fatores analisados. O primeiro dígito é referente ao fator Uso da Terra/Cobertura Vegetal; o segundo dígito é referente ao fator relevo, e o terceiro dígito, referente ao fator solos. Por fim acrescenta-se o dígito referente ao clima.

De acordo com a proposição metodológica de ROSS (1994), o que diferencia as Unidades Ecodinâmicas de Instabilidade Potencial (Estáveis) das Unidades Ecodinâmicas de Instabilidade Emergente (Instáveis) é o fator
Uso da Terra/Cobertura Vegetal. Portanto, nas áreas cujo uso da terra foi classificado como 1 , ou seja, com tipo de cobertura vegetal predominantemente de floresta, matas naturais ou florestas cultivadas com biodiversidade, com grau de proteção muito alto, foram automaticamente classificados como Unidades Ecodinâmicas de Instabilidade Potencial. As demais áreas, com outros tipos de cobertura vegetal, foram classificadas como Unidades Ecodinâmicas de Instabilidade Emergente.

Os graus de fragilidade associados dependeram da análise dos demais fatores: a combinação entre relevo, solos e clima. Como o fator clima só teve uma ocorrência na área de estudo, neste caso, não terá alterações. 
Para classificar as Unidades Ecodinâmicas de Instabilidade Potencial foi elaborada uma matriz de correlações entre os fatores relevo e solos, visto que o fator Uso da terra/Cobertura Vegetal será único para todas as combinações: Florestas/matas naturais, com grau de proteção muito alto (1). O Quadro 8 apresenta a matriz de correlação para as Unidades Ecodinâmicas de Instabilidade Potencial.

\section{Quadro 8 - Matriz de correlação entre relevo e solos para classificação das Unidades Ecodinâmicas de Instabilidade Potencial}

\section{Matriz de Correlação Rel evo x Solos Unidades Ecodinâmicas de Instabilidade Potencial (Estáveis)}

CONSTANTES- Fator Uso da Terra / Cobertura vegetal = grau de proteção (1) Fator Clima $=$ grau de fragilidade (3)

\begin{tabular}{|c|c|c|c|c|c|}
\hline \multirow[b]{2}{*}{$\begin{array}{c}\text { Grau de Fragilidade dos tipos de relevo } \\
\text { e declividade }\end{array}$} & \multicolumn{5}{|c|}{ Grau de Fragilidade dos Solos } \\
\hline & $\begin{array}{l}\text { Muito } \\
\text { baixo } \\
(1) \\
(-)\end{array}$ & $\begin{array}{l}\text { Baixo } \\
\text { (2) } \\
(-)\end{array}$ & $\begin{array}{l}\text { Médio } \\
\text { (3) } \\
\text { LVA4 }\end{array}$ & $\begin{array}{c}\text { Alto } \\
\text { (4) } \\
\text { PVA } 13\end{array}$ & $\begin{array}{l}\text { Muito } \\
\text { Alto (5) } \\
\text { RL8 } \\
\text { RL9 } \\
\text { GX9 }\end{array}$ \\
\hline $\begin{array}{l}\text { Muito Baixo (1) } \\
\text { Tp - Topos planos (0 a } 12 \% \text { decl.) }\end{array}$ & - & - & 13 & 14 & 15 \\
\hline $\begin{array}{l}\text { Baixo (2) } \\
\text { Tc - Topos convexos (0 a } 12 \% \text { decl.) } \\
\text { Vc1 - Vertentes convexas (3 a } 12 \% \text { decl.) } \\
\text { Pt - Patamares planos (3 a } 12 \% \text { decl.) }\end{array}$ & - & - & 23 & 24 & 25 \\
\hline $\begin{array}{l}\text { Médio (3) } \\
\text { Vcc - Vertentes côncavas (3 a } 12 \% \text { decl.) } \\
\text { Vc2 - Vertentes convexas (12 a } 30 \% \text { decl.) }\end{array}$ & - & - & 33 & 34 & 35 \\
\hline $\begin{array}{l}\text { Alto (4) } \\
\text { Vr2 - Vertentes retilíneas (12 a 30\% decl.) }\end{array}$ & - & - & 43 & 44 & 45 \\
\hline $\begin{array}{l}\text { Muito Alto (5) } \\
\text { Vr1 - Vertentes retilíneas (decl. > 30\%) } \\
\text { Planície Fluvial ( } 0 \text { a 3\% ded.) }\end{array}$ & - & $\overline{-}$ & 53 & 54 & 55 \\
\hline \multicolumn{6}{|c|}{$\begin{array}{l}\text { LEGENDA } \\
\text { (-) Sem ocorrência na área de estudo. } \\
\text { LVA4 - Latossolo Vermel ho-Amarelo de textura média } \\
\text { PVA13 - Argissolos Vermelho-Ama rel o de textura média/arenosa } \\
\text { GL8 e RL9 - Neossolos Litólicos com afl oramento de rochas } \\
\text { GX9 - Gleissolos Háplicos }\end{array}$} \\
\hline
\end{tabular}

Org.: AMARAL (2008).

Para classificar as Unidades Ecodinâmicas de Instabilidade Emergente foi elaborada uma matriz de correlações entre os fatores uso da terra e relevo/solos (combinados), visto que o fator Uso da Terra/Cobertura Vegetal terá variações. O Quadro 9 apresenta a matriz de correlação para as Unidades Ecodinâmicas de Instabilidade Potencial. 
As Unidades Ecodinâmicas na análise da fragilidade ambiental do

\section{Quadro 9 - Matriz de correlação entre uso da terra, relevo e solos para classificação das Unidades Ecodinâmicas de Instabilidade Emergente}

\begin{tabular}{|c|c|c|c|c|c|}
\hline $\begin{array}{r}\text { Matriz de Correla } \\
\text { Unidades Ecodinamicas }\end{array}$ & $\begin{array}{l}\text { soda T } \\
\text { stabilid }\end{array}$ & $\begin{array}{l}\text { erra } x \text { Rele } \\
\text { la de E merg }\end{array}$ & $\begin{array}{l}\text { ox Solc } \\
\text { nte (In }\end{array}$ & áveis ) & \\
\hline & Grau de & Fragilid a de & do Uso d & Terra/Cobe & a Vegetal \\
\hline $\begin{array}{c}\text { Grau de Fragilidade dos solos + tipos de } \\
\text { vertentes e declividade }\end{array}$ & $\begin{array}{c}\text { M u ito } \\
\text { b a ixo } \\
(1) \\
(-)\end{array}$ & $\begin{array}{l}\text { Baixo ( 2) } \\
\text { Capoeira }\end{array}$ & $\begin{array}{c}\text { M éd io } \\
(3) \\
(-)\end{array}$ & $\begin{array}{c}\text { Alto (4) } \\
\text { Pastagem } \\
\text { A gricultura }\end{array}$ & $\begin{array}{c}\text { Muito } \\
\text { A Ito (5) } \\
\text { Solo } \\
\text { exposto }\end{array}$ \\
\hline $\begin{array}{l}\text { Muito Baixo (1) } \\
(-)\end{array}$ & - & - & - & - & - \\
\hline $\begin{array}{l}\text { Baixo (2) } \\
(-)\end{array}$ & - & - & - & - & - \\
\hline Médio ( 3 ) & - & & - & & \\
\hline Tp + LVA 4 (13) & & 213 & & 413 & 513 \\
\hline Tc + LVA 4 (23) & & 223 & & 423 & 523 \\
\hline V c1 + LVA4 (23) & & & & $\begin{array}{l}423 \\
423\end{array}$ & $\begin{array}{l}523 \\
523\end{array}$ \\
\hline Pt + LVA4 (23) & & 223 & & $\begin{array}{l}423 \\
433\end{array}$ & $\begin{array}{l}523 \\
533\end{array}$ \\
\hline $\begin{array}{l}V c c+L V A 4(33) \\
V c 2+\operatorname{LVA} 4(33)\end{array}$ & & $\begin{array}{l}233 \\
233\end{array}$ & & $\begin{array}{l}433 \\
433\end{array}$ & 533 \\
\hline Alto (4) & - & & - & & \\
\hline Tp + PVA13 (14) & & 214 & & 414 & 514 \\
\hline TC + PVA13 (24) & & 224 & & 424 & 524 \\
\hline V c1 + PVA 13 (24) & & 224 & & 424 & 524 \\
\hline$P t+P V A 13(24)$ & & 224 & & 424 & 524 \\
\hline$V C C+P V A 13(34)$ & & 234 & & 434 & 534 \\
\hline V $c 2+$ PVA 13 (34) & & 234 & & 434 & 534 \\
\hline$V r 2+\operatorname{LVA} 4(43)$ & & 243 & & 443 & 543 \\
\hline$V r 2+P V A 13(44)$ & & 244 & & 444 & 544 \\
\hline Muito Alto (5) & - & & - & & \\
\hline$T p+R L 8$ (15) & & 215 & & 415 & 515 \\
\hline$T p+R L 9(15)$ & & 215 & & 415 & $\begin{array}{l}515 \\
515\end{array}$ \\
\hline$T p+G \times 9(15)$ & & 215 & & 415 & 515 \\
\hline $\mathrm{TC}+\mathrm{RL8}(25)$ & & 225 & & $\begin{array}{l}425 \\
425\end{array}$ & 525 \\
\hline $\begin{array}{l}1 \mathrm{C}+\mathrm{R} L 9(25) \\
\mathrm{TC}+\mathrm{G} \times 9(25)\end{array}$ & & $\begin{array}{l}225 \\
225\end{array}$ & & 425 & 525 \\
\hline$V c 1+R L 8$ (25) & & 225 & & 425 & 525 \\
\hline$V_{c 1}+R L 9$ (25) & & 225 & & 425 & 525 \\
\hline$V c 1+G \times 9(25)$ & & 225 & & 425 & 525 \\
\hline$P t+R L 8(25)$ & & 225 & & 425 & 525 \\
\hline$P t+R L 9(25)$ & & 225 & & 425 & 525 \\
\hline$P t+G \times 9(25)$ & & 225 & & 425 & 525 \\
\hline$V c c+R L 8(35)$ & & 235 & & 435 & 535 \\
\hline$V c c+R L 9$ (35) & & 235 & & 435 & 535 \\
\hline$V c c+G \times 9$ (35) & & 235 & & 435 & 535 \\
\hline$V c 2+R L 8$ (35) & & 235 & & 435 & 535 \\
\hline$V c 2+R L 9$ (35) & & 235 & & 435 & 535 \\
\hline$V c 2+G \times 9$ (35) & & 235 & & 435 & 535 \\
\hline$V r 2+R L 8(45)$ & & 245 & & 445 & 545 \\
\hline$V r_{2}+R L 9(45)$ & & 245 & & 445 & 545 \\
\hline$V r 2+G \times 9(45)$ & & 245 & & 445 & 545 \\
\hline Vr1 + LVA 4 (53) & & 253 & & 453 & 553 \\
\hline Plan. Fluvial + LVA 4 (53) & & 253 & & 453 & 553 \\
\hline Vr1 + PVA13 (54) & & 254 & & 454 & 554 \\
\hline Plan. Fluvial + PVA13(54) & & 254 & & 454 & 554 \\
\hline$V r 1+R L 8$ ( 55$)$ & & 255 & & 455 & 555 \\
\hline Plan. Fluvial + RL8 (55) & & 255 & & 455 & 555 \\
\hline$V r 1+R L 9(55)$ & & 255 & & 455 & 555 \\
\hline $\begin{array}{l}\text { Plan. Fluvial + RL9 (55) } \\
\text { Vr1 }{ }^{2} \times 9(55)\end{array}$ & & $\begin{array}{l}255 \\
255\end{array}$ & & $\begin{array}{l}455 \\
455\end{array}$ & $\begin{array}{l}555 \\
555\end{array}$ \\
\hline $\begin{array}{l}\text { Vr1 + GX9(55) } \\
\text { Plan. Fluvial + GX9 (55) }\end{array}$ & & $\begin{array}{l}255 \\
255\end{array}$ & & $\begin{array}{l}455 \\
455\end{array}$ & $\begin{array}{l}555 \\
555\end{array}$ \\
\hline LEG END A : & $\mathrm{Vr} 2$ & - Vertentes ret & ilíneas (12 & $30 \%$ decl.) & \\
\hline (-) Sem ocorrência na área de estudo. & $\mathrm{Vr} 1-$ & - Vertentes ret & ilíneas (de & $>30 \%)$ & \\
\hline T́p - To pos planos (0 a $3 \%$ decl.) & & Fluvial - Plan & cie fluvial & a $3 \%$ decl.) & \\
\hline 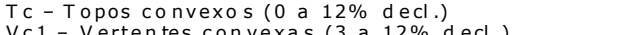 & LVA4 & - Latossolo V & erm elh o-A & arelo de textur & édia \\
\hline $\begin{array}{l}\text { Vc1-Vertentes convexas ( } 3 \text { a } 12 \% \text { decl.) } \\
\text { Pt - Patamares planos }(3 \text { a } 12 \% \text { decl.) }\end{array}$ & médi & $\begin{array}{l}3-\text { A rgis } \\
\text { a/a renosa }\end{array}$ & solos v & elho-Ama relo & e textura \\
\hline Vcc-Vertentes côncavas ( 3 a $12 \%$ decl.) & $R L 8$ & e RL9-N eoss & os Litóli & co $m$ a florame & roch as \\
\hline Vc2 - Vertentes convexas ( 3 a $12 \%$ decl.) & $\mathrm{G} \times 9$ & - Gleis solos H & plico & & \\
\hline
\end{tabular}

Org.: AMARAL (2008) 
As matrizes descritas anteriormente representam as combinações que podem ocorrer entre os diferentes tipos de relevo, solos e uso da terra/cobertura vegetal. Deve-se esclarecer que não ocorrerão todas as combinações necessariamente. O Quadro 10 apresenta a síntese das possíveis combinações numéricas de definição dos polígonos da área de estudo. Ao final de cada grau de fragilidade identificado foi acrescido o dígito 3, referente ao clima.

\section{Quadro 10 - Classificação numérica por grau de fragilidade das Unidades Ecodinâmicas de Instabilidade Potencial e Emergente (possíveis combinações).}

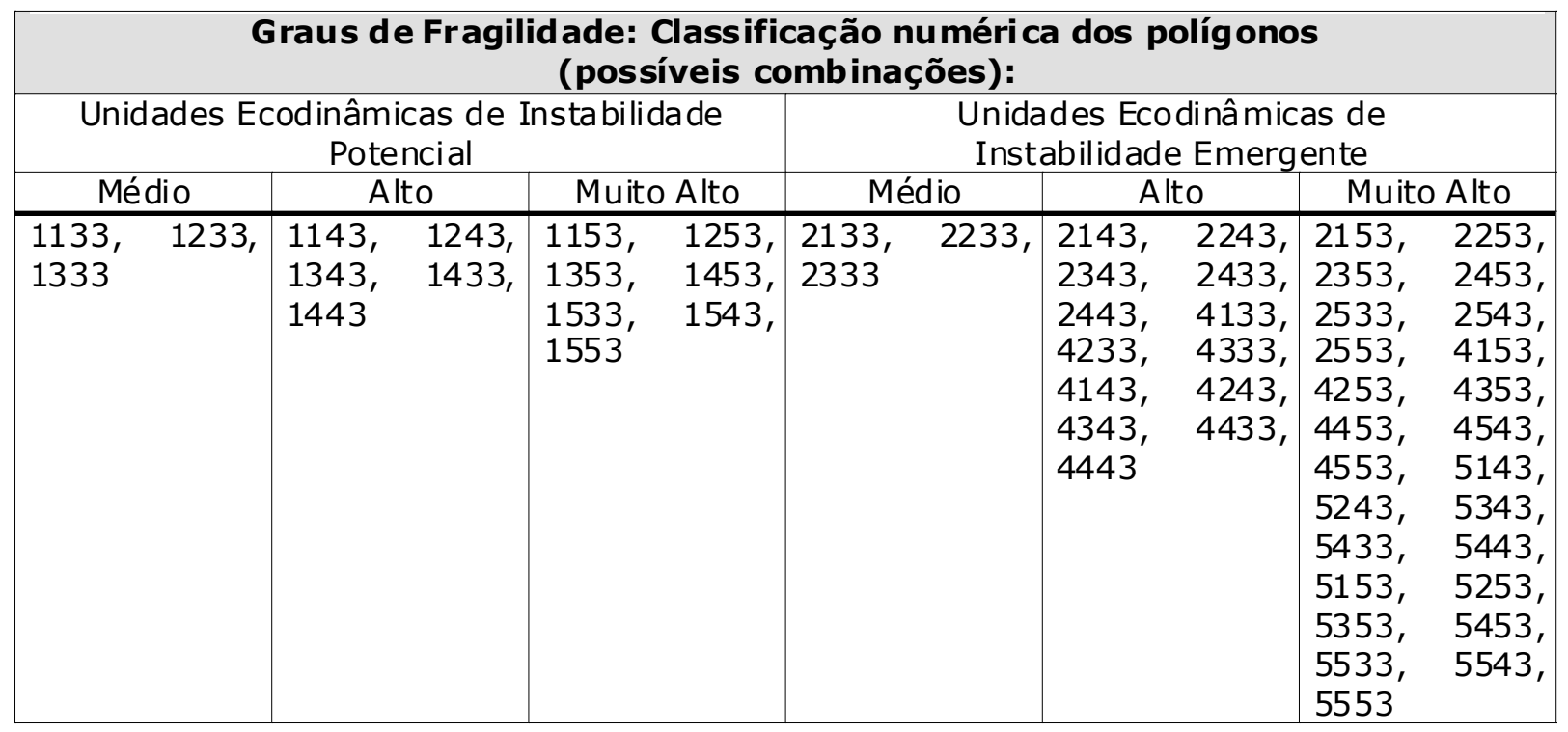

Org.: AMARAL (2008)

Para obter as correlações entre os polígonos definidos nas cartas de Uso da Terra, Geomorfológica e Pedológica, foi elaborado um algoritmo no módulo Legal do Software Spring para alcançar como produto final a carta síntese, a Carta das Unidades Ecodinâmicas de Instabilidade Potencial e Emergente. A classificação das Unidades Ecodinâmicas e seus respectivos graus de fragilidade podem ser visualizados na Figura 2.

Em análise ao resultado obtido pela Carta Síntese, tanto as Unidades Ecodinâmicas de Instabilidade Potencial como as de Instabilidade Emergente apresentaram três graus de fragilidade: médio, alto e muito alto, descritos detalhadamente a seguir.
A) Unidades Ecodinâmicas de Instabilidade Potencial.

Correspondem às áreas cuja cobertura vegetal é de floresta/matas naturais, e, portanto, o grau de proteção é muito alto, proporcionado pela densidade da vegetação e presença de serrapilheira. A presença da vegetação densa impede que o solo seja atingido diretamente pelas águas pluviais, evitando a ação do salpicamento. A presença da serrapilheira, assim como as próprias raízes presentes no solo, impedem a erosão laminar e linear. Nos testes com o infiltrômetro verificou-se rápida infiltração e ausência de saturação, tanto em superfície como em subsuperfície, demonstrando boa permeabilidade e porosidade dos solos, o que 


\section{Figura 2 - Carta das Unidades Ecodinâmicas de Instabilidade Potencial e Emergente}

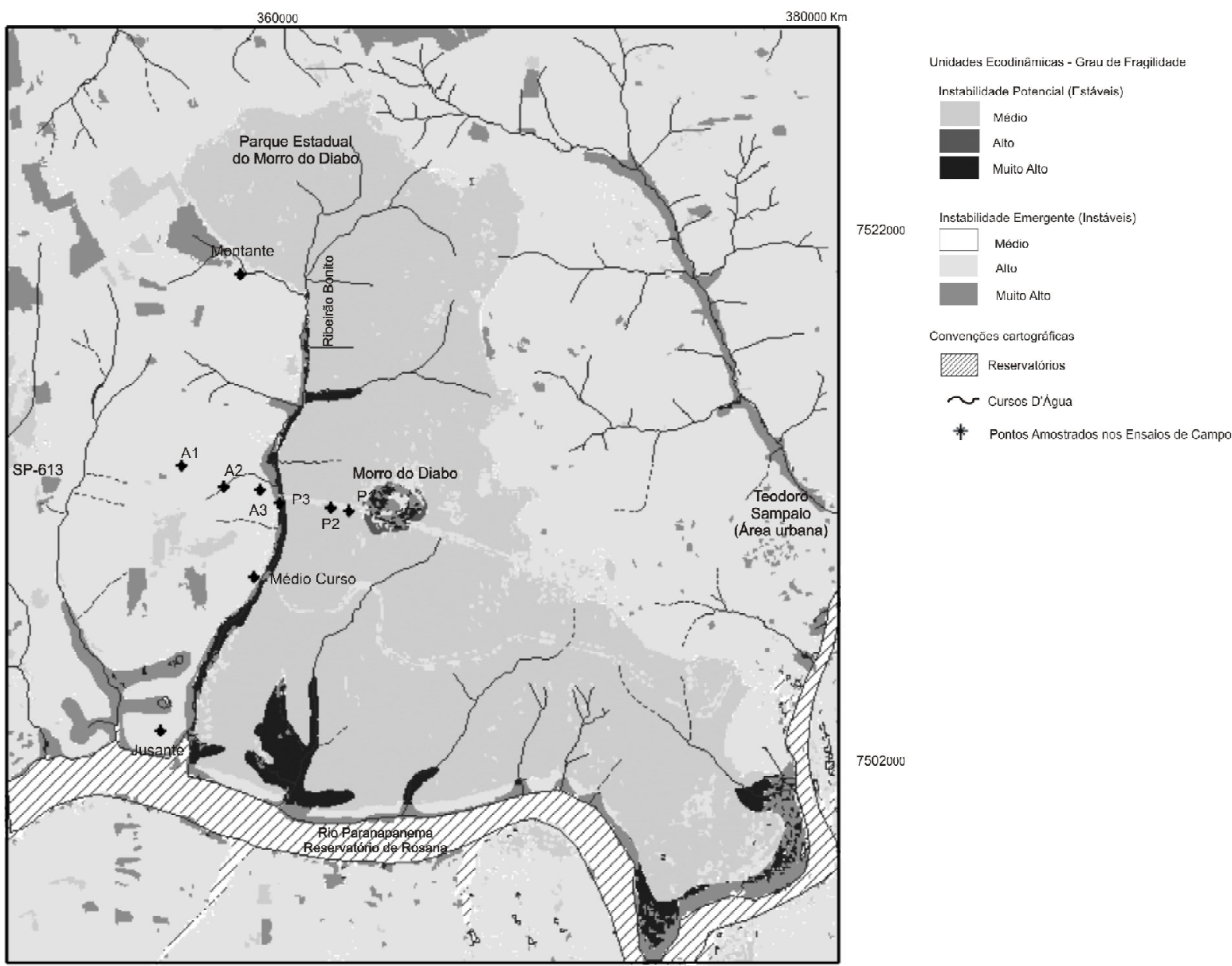

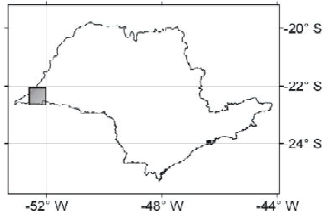

evita o escoamento superficial. Entretanto, essas áreas estão restritas ao Parque Estadual do Morro do Diabo e outros pequenos fragmentos ainda preservados, principalmente a oeste do Parque. a) Grau de Fragilidade Médio (1133, 1233 e 1333): são áreas de vertentes côncavas e convexas, topos e patamares planos, com declividades baixas e médias, associadas aos Latossolos Vermelho-Amarelos. Ocorrem em 
praticamente toda a extensão do Parque, exceto no Morro do Diabo, nas planícies fluviais e nas áreas antropizadas. Ocupam 27,60\% da área de estudo $\left(318 \mathrm{~km}^{2}\right)$.

b) Grau de Fragilidade Alto (1143, 1243, 1343, 1433, 1443): são áreas de vertentes côncavas e convexas, topos e patamares planos, com declividades baixas e médias, associadas aos Argissolos Vermelho-Amarelos e de vertentes retilíneas de declividade média associadas aos Latossolos Vermelho-Amarelos e aos Argissolos Vermelho-Amarelos. Ocorrem restritamente no Morro do Diabo. Ocupam 0,09\% da área de estudo $\left(1 \mathrm{~km}^{2}\right)$.

c) Grau de Fragilidade Muito Alto (1153, 1253, $1353,1453,1533,1543,1553$ ): ocorrem em todos os tipos de vertentes e declividades, incluindo as planícies fluviais, desde que associados aos Neossolos Litólicos e aos Gleissolos Háplicos e, no caso das vertentes retilíneas de alta declividade, podem estar associados também aos Latossolos Vermelho-Amarelos e aos Argissolos Vermelho-Amarelos. As áreas de planícies fluviais, que, embora sejam consideradas estáveis pela cobertura florestal, são classificadas como grau de fragilidade potencial muito forte por se tratar de áreas inundáveis. As frequentes cheias nessas áreas promovem o carreamento dos sedimentos finos presentes nas margens dos corpos d'água, que podem provocar assoreamento. Na área de estudo, estes sedimentos são carreados para o Reservatório de Rosana, no Rio Paranapanema. Em longo prazo estes sedimentos depositados nos reservatórios podem comprometer sua capacidade. Ocupam $1,75 \%$ da área de estudo $\left(20 \mathrm{~km}^{2}\right)$.

B) Unidades Ecodinâmicas de Instabilidade Emergente.

Correspondem às áreas cuja cobertura vegetal é de capoeira, pastagem, agricultura ou solo exposto. O grau de proteção varia de acordo com a cobertura vegetal presente, conforme os graus de fragilidade descritos a seguir.

a) Grau de Fragilidade Médio (2133, 2233, 2333): são áreas vertentes côncavas e convexas, topos e patamares planos, com declividades baixas e médias, associadas aos Latossolos VermelhoAmarelos, onde a vegetação predominante é a capoeira ou vegetação de mata em regeneração. Ocorrem esparsas em pequenos fragmentos por toda a área de estudo e ao longo das margens dos corpos d'água. Este tipo de vegetação, menos densa do que as áreas de floresta/mata natural, oferece certo grau de proteção aos solos. Observou-se que as bordas do Parque apresentam vegetação de capoeira ou vegetação de mata alterada, assim como algumas áreas no interior do Parque como ao longo da rodovia e da antiga ferrovia que cruzam o Parque (áreas alteradas) e próximo à margem do Reservatório de Rosana (vegetação de brejo - alterada pelo nível d'água mais alto devido ao enchimento do reservatório). Ocupam $8,73 \%$ da área de estudo $\left(101 \mathrm{~km}^{2}\right)$.

b) Grau de Fragilidade Alto $(2143,2243,2343$, 2433, 2443, 4133, 4233, 4333, 4143, 4243, 4343, 4433, 4443): são áreas de vertentes côncavas e convexas, topos e patamares planos, com declividades baixas e médias, associadas aos Argissolos Vermelho-Amarelos e de vertentes retilíneas de declividade média associadas aos Latossolos Vermelho-Amarelos e aos Argissolos Vermelho-Amarelos, onde a cobertura vegetal pode ser capoeira, pastagem ou agricultura. Ocorrem em grande parte da área de estudo, nos assentamentos e fazendas. As áreas destinadas à pastagem sofrem diversos tipos de impactos: podem estar relacionados à erosão de sulcos entre as braquiárias plantadas ou ao pisoteio do gado em linhas preferenciais, responsável pela erosão linear encontrada nestes trechos. As áreas de agriculturas diversas, que ocorrem predominantemente nos assentamentos, também desencadeiam impactos: é rara a aplicação de 
práticas conservacionistas no manejo dos solos, o que faz com que a superfície seja exposta em alguns períodos do ano (entressafra), favorecendo a erosão laminar e linear, e o uso de maquinário pesado causa compactação dos horizontes superficiais do solo, o que dificulta a infiltração da água no solo e favorece a erosão laminar e linear. Além de propiciar a erosão, estes impactos também causam o empobrecimento dos solos, exigindo outras medidas corretivas para mantê-los férteis. Essas características ocorreram em todos os pontos

\section{Figura 3 - Distribuição das Unidades Ecodinâmicas de Instabilidade Potencial e Emergente, por grau de fragilidade, área ocupada em $\mathbf{k m}^{2}$ e porcentagem.}

\section{Graus de Fragilidade no Parque Estadual do Morro do Diabo e entorno - Teodoro Sampaio/SP (Classe; Área ocupada em km²; Porcentagem da área ocupada)}

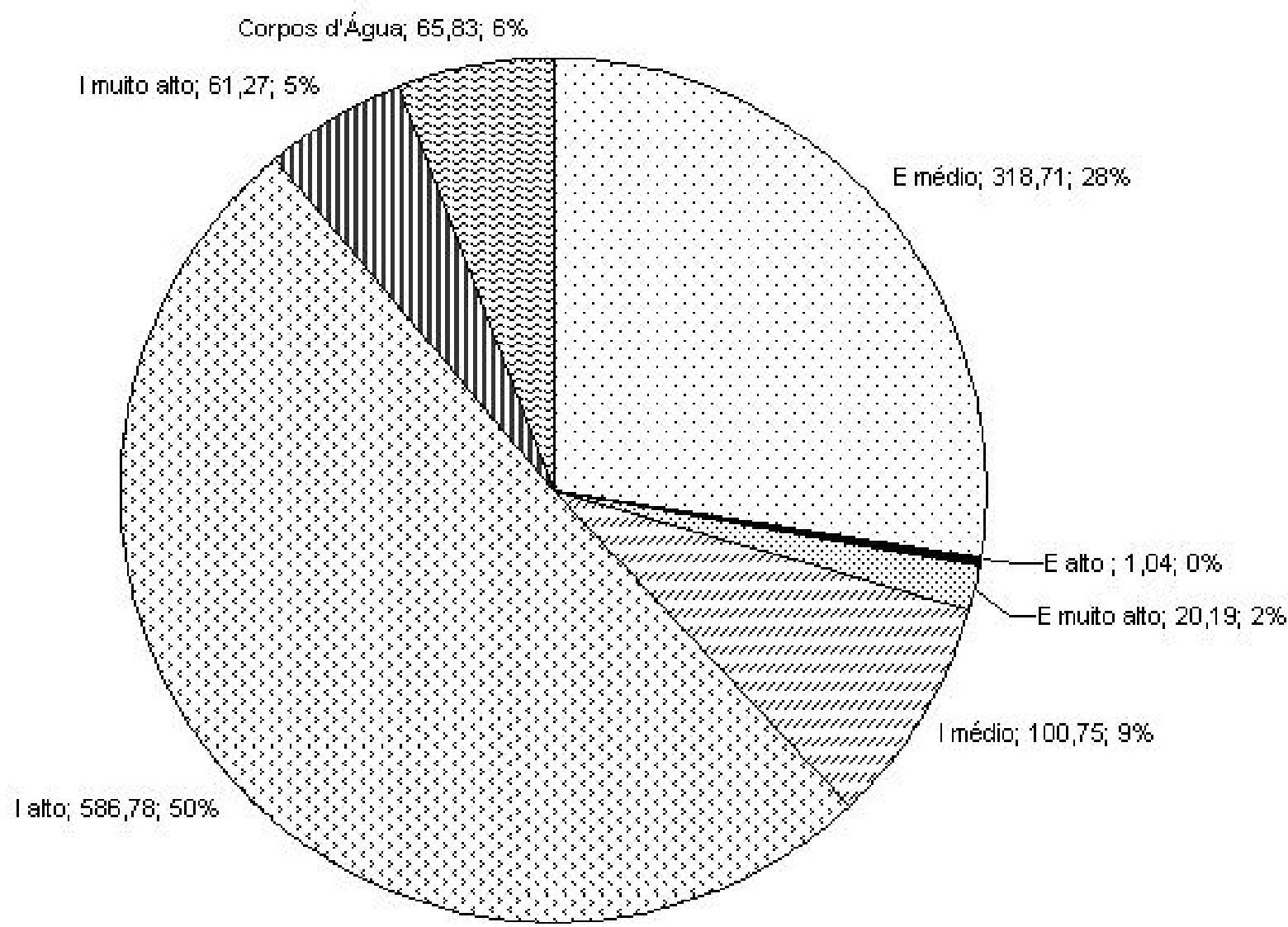

E - Unidades Ecodinâmicas de Instabilidade Potencial (Estáveis)

I- Unidades Ecodinâmicas de Instabilidade Emergente (Instáveis) 
amostrados na área de assentamento. Ocupam $50,82 \%$ da área de estudo (587 $\left.\mathrm{km}^{2}\right)$.

c) Grau de Fragilidade Muito Alto (2153, 2253, 2353, 2453, 2533, 2543, 2553, 4153, 4253, $4353,4453,4543,4553,5143,5243,5343,5433$, $5443,5153,5253,5353,5453,5533,5543$, 5553): ocorrem em todos os tipos de vertentes e declividades, incluindo as planícies fluviais, desde que associados aos Neossolos Litólicos e aos Gleissolos Háplicos e, no caso das vertentes retilíneas de alta declividade, podem estar associados também aos Latossolos VermelhoAmarelos e aos Argissolos Vermelho-Amarelos. Nestas áreas o uso da terra pode ser de capoeira, pastagem, agricultura ou solo exposto. Incluemse aqui as áreas de planícies fluviais sem cobertura florestal densa, por se tratar de áreas inundáveis, que têm as mesmas implicações das planícies fluviais das Unidades Ecodinâmicas de Instabilidade Potencial. As áreas de uso da terra destinadas à capoeira, pastagem e agriculturas têm as mesmas implicações escritas para as Unidades Ecodinâmicas de Instabilidade Emergente de grau de fragilidade alta, acrescidas do fato de estarem localizadas em solo raso e com más condições de permeabilidade e porosidade. Correspondem também às áreas de solo exposto, que em alguns locais da área de estudo coincidem como áreas destinadas ao plantio da cana-de-açúcar em seu período de queima. O solo exposto, sem nenhum tipo de cobertura vegetal, associado aos solos de textura média e arenosa, é muito erodível, de forma que podem ocorrer processos de erosão laminar e linear. Ocupam 5,31\% da área de estudo (61 $\mathrm{km}^{2}$ ).

A distribuição dos graus de fragilidade por área ocupada pode ser visualizada na Figura 3.

\section{Considerações Finais}

Com o objetivo de avaliar as áreas suscetíveis à degradação no Parque Estadual do Morro do Diabo e entorno (Teodoro Sampaio/SP) foi desenvolvido um estudo com a aplicação do conceito de Unidades Ecodinâmicas. Foram analisados integradamente dados de uso da terra (componente antrópica) e de relevo, solos e clima (componentes ambientais), em escala 1:50.000, para definir as Unidades Ecodinâmicas de Instabilidade Emergente para áreas antropizadas e de Instabilidade Potencial para áreas naturais, com graus de fragilidade variando de muito baixo a muito alto.

Para subsidiar o estudo foram coletados dados secundários e de campo, de forma a classificar hierarquicamente cada um dos fatores analisados (uso da terra/cobertura vegetal, relevo, solos e clima).

Para caracterizar o fator uso da terra/ cobertura vegetal foram considerados dados de densidade da cobertura vegetal e a presença de práticas conservacionistas; para caracterizar o fator relevo, foram considerados dados sobre os tipos de vertentes e índices de declividade; para o fator solos foram considerados dados sobre textura, profundidade e espessura dos horizontes superficiais e subsuperficiais, permeabilidade e compactação; para o fator clima foram considerados dados sobre a distribuição anual e intensidade da pluviometria.

Para avaliar o fator uso da terra/cobertura vegetal foi feita uma interpretação da imagem de satélite Landsat TM5, com averiguações de campo. Os tipos de uso da terra identificados foram florestas/matas naturais, capoeira, pastagem e agriculturas diversas sem práticas conservacionistas, áreas desmatadas e queimadas, solo exposto por arado/gradeação e solo exposto ao longo de caminhos e estradas.

Para avaliar o fator relevo e elaborar a Carta Geomorfológica da área de estudo foi feita uma compartimentação por tipos de vertentes, utilizando-se a classificação taxonômica, associando-se os índices de declividade. Os tipos de formas de relevo encontrados na área de estudo foram: as Colinas amplas e baixas, cujos tipos de vertentes são predominantemente convexas de baixas declividades ( 3 a $12 \%$ ), algumas ocorrências de vertentes côncavas, de mesma declividade e alguns topos convexos, com declividades entre 0 a $12 \%$. Outro tipo de forma 
de relevo encontrado foi o morro com topo aplanado ou tabular, correspondente ao Morro do Diabo, única grande elevação da Bacia. Os tipos de vertentes encontrados no morro correspondem às vertentes convexas de médias declividades ( 12 a 30\%), vertentes retilíneas de médias e altas declividades (de 12 a $30 \%$ e $>30 \%$, respectivamente), topos planos, com declividades de 0 a $3 \%$, patamares planos, de mesma declividade e topos convexos, com declividades de 0 a $12 \%$. Por fim, as planícies fluviais às margens do Ribeirão Bonito e seus afluentes, com declividades de 0 a $3 \%$.

Para avaliar o fator solos foram feitos levantamentos secundários (Carta Pedológica do Estado de São Paulo) e levantamentos de campo, com análises granulométricas e testes para averiguar a permeabilidade/compactação. Foram amostrados pontos em diferentes compartimentos de relevo e uso da terra.

Nas áreas onde a declividade está próxima de $12 \%$, foram identificados solos Argissolos Vermelho-Amarelos (PVA13) e nas áreas de menores declividades Latossolos VermelhoAmarelos (LVA4). Às margens dos rios afluentes e do Rio Paranapanema (Reservatório de Rosana), foram identificados solos Gleissolos Háplicos (GX9). No Morro do Diabo identificaram-se Neossolos Litólicos (RL8 e RL9). Os solos são predominantemente arenosos, influenciados diretamente pela composição do subsolo, o que causa uma rápida e profunda infiltração da água que leva consigo os minerais e empobrece o solo superficial. Como os arenitos da área são finos, o impacto da chuva desagrega o solo com facilidade e estes são carreados, causando erosão em área sem vegetação ou com cultivos sem práticas conservacionistas e a sedimentação dessas partículas em rios ou reservatórios.

Para avaliar o fator clima, foi feito levantamento de dados junto ao posto pluviométrico instalado na área de estudo. A situação pluviométrica característica dessa área é de distribuição pluviométrica anual desigual, com períodos secos entre 2 e 3 meses no inverno, e no verão com maiores intensidades de dezembro a março. A média anual é de 1500 mm/a.
A partir da análise integrada pôde-se notar que não se verificam diferenças representativas de degradação e graus de fragilidade entre as posições dos pontos amostrados no relevo (alta, média e baixa vertente), mas sim em relação à presença ou não de cobertura vegetal florestal (Unidades Ecodinâmicas de Instabilidade Potencial (Estáveis) e de Instabilidade Emergente (Instáveis)).

Verificou-se que as altas taxas pluviométricas concentram-se nos meses de verão, quando as chuvas torrenciais favorecem o escoamento superficial e abrem cicatrizes erosivas que rapidamente podem evoluir de ravinas para voçorocas, principalmente em função das condições físicas dos solos, que são arenosos, do que o relevo, que apresenta em geral vertentes com baixos gradientes topográficos, vertentes longas e baixas declividades. Dessa forma, o fator primordial de estabilidade ambiental é a presença de cobertura vegetal florestal densa e solo recoberto de serrapilheira.

$\mathrm{Na}$ área restrita ao Parque Estadual do Morro do Diabo, classificada como Unidade Ecodinâmica de Instabilidade Potencial, não se encontram marcas erosivas evidentes, frente ao alto grau de proteção do solo contra a erosão proporcionado pela cobertura florestal natural. No Morro do Diabo há um forte potencial de erosão devido às altas declividades das vertentes ali encontradas. Entretanto não se observou nenhum ponto com marcas de processos erosivos agressivos, em função da proteção do solo pela floresta.

No restante das áreas, classificadas como Unidades Ecodinâmicas de Instabilidade Emergente, há a influência do fator uso da terra, que torna o ambiente bastante frágil, pois em muitos locais sequer existe alguma cobertura vegetal, encontrando-se solo totalmente exposto. Há ainda as plantações de cana-de-açúcar, que têm queimas periódicas, deixando o solo exposto à ação das águas por determinado período de tempo ao longo do ano.

O pisoteio do gado e a implantação das culturas diversificadas fazem com que o solo fique 
exposto às intempéries, e qualquer chuva pode carrear grande quantidade de partículas, o que acaba causando o assoreamento nos rios e reservatórios. O tipo de pastagem cultivada com capim braquiária também proporciona o aparecimento de sulcos entre os tufos da vegetação. Em estradas ou próximo às cercas das propriedades são encontradas cicatrizes de erosão e até mesmo voçorocas.

Desta forma, pode-se considerar que a intervenção humana, verificada pela alteração no uso da terra, é o fator preponderante nos casos de processos erosivos observados na área. Este uso expõe o solo à alterações muitas vezes irreversíveis, caso não haja uma intervenção rápida e prática, como a recuperação de áreas muito suscetíveis à erosão. Processos como o voçorocamento têm custo muito alto para serem revertidos e, às vezes, são até ineficazes. Deste modo, percebese ser melhor prevenir, do que no futuro ter que recuperar estas áreas. A textura médiaarenosa e arenosa favorece a desagregação do solo, tornando difícil a interrupção dos processos erosivos instalados. Verifica-se também que se implantou o sistema de curvas de nível em algumas propriedades agrícolas para conter a erosão.

As planícies fluviais apesar de se localizarem em áreas de baixa declividade $(0 \mathrm{a}$ $3 \%)$, foram classificadas como sendo de grau de fragilidade muito alto de acordo com o índice de relevo, porque estas áreas estão condicionadas às inundações constantes e elevação do nível do lençol freático, proporcionando o carreamento de sedimentos para os cursos d'água.

$\mathrm{Na}$ área em estudo, assim como em todo o Pontal do Paranapanema, as terras são pouco férteis, o que restringe o plantio, sobretudo nos assentamentos agrários, onde o grau de mecanização e práticas conservacionistas quase não ocorrem. As culturas, além do baixo aproveitamento potencial, fazem com que o solo seja exposto frequentemente, o que diminui cada vez mais sua capacidade de uso agrícola.
A compactação do solo e a exposição da superfície por meio da diminuição do grau de proteção, comparado à proteção que havia com a vegetação natural fazem com que ocorra o escoamento superficial, que por sua vez, proporciona a erosão laminar e linear.

Um dos fatores de desgaste que mais seriamente tem contribuído para a improdutividade dos solos é a erosão hídrica acelerada pelo homem com as práticas inadequadas de ocupação e agricultura perante os tipos de solos e clima.

Por meio dos resultados desta análise, fica confirmada a influência da cobertura vegetal florestal, onde a mudança de uso (do estado natural - estável - para o antrópico - instável) é o que desencadeia os processos erosivos.

Constatado o principal problema, procura-se fazer breves sugestões em relação às diretrizes que devem caber ao planejamento ambiental.

A degradação ambiental no local ocorre desde que a vegetação original foi derrubada para dar lugar às monoculturas extensivas. Observando os dados de cobertura florestal do Estado de São Paulo verificou-se o avanço do desmatamento e a consequente ocupação do território, de forma que somente restou Mata Atlântica nas Unidades de Conservação e em pequenos fragmentos de vegetação em áreas particulares. Tratando-se aqui de uma área onde se encontra o principal fragmento de Mata Atlântica do interior do Estado de São Paulo, o planejamento deve objetivar sua preservação e manutenção.

Verificou-se que na área do Parque não ocorrem processos erosivos severos, exceto nas áreas com intervenção humana, como por exemplo, onde a antiga ferrovia cruzava as matas. Nesses locais, agora abandonados com a desativação da ferrovia, ocorrem processos de erosão em estágio avançado, como as voçorocas. É importante fazer a contenção do fluxo d'água das vertentes com canaletas e caixas de retenção temporária, desviando a 
água para que não continue atingindo a voçoroca e consequentemente aumentando sua proporção. Deve ser feito o reflorestamento das áreas atingidas, pois o solo exposto é carreado facilmente, o que causa assoreamento dos cursos d'água e do Reservatório de Rosana, no Rio Paranapanema.

Para melhorar as condições ambientais da área, é importante não só a preservação do Parque, mas também do entorno, melhorando inclusive a qualidade de vida dos moradores.

$\mathrm{Na}$ área dos assentamentos e nas fazendas devem ser incentivados o sistema de curvas de nível e as redes de terraços para contenção de escoamento superficial e indução da infiltração, pois controlam a erosão laminar e o assoreamento. É necessário ainda impedir que o solo fique exposto, já que além da erosão laminar, causa o empobrecimento do solo, adotando-se técnicas de cultivo adequadas, como o plantio na palha (plantio direto).

A diversificação da produção, o reflorestamento de áreas e a capacitação técnica dos assentados devem ser algumas das prioridades para que seja obtido sucesso na produtividade, melhoria na qualidade ambiental e de vida da população.

Esses são apenas alguns dos problemas identificados aos quais se propõem formas de tentar minimizar seus impactos. Muitos outros poderão ser diagnosticados em estudos em escalas de maior detalhe e em estudos com outros enfoques, como por exemplo, o agrário e o socioeconômico, aos quais esta análise pode servir de subsídio.

Ressalta-se que a metodologia, como qualquer modelo que possa ser aplicado, é uma representação da realidade, de acordo com a perspectiva de enfoque. Portanto, em algumas áreas o resultado da fragilidade pode não condizer com a realidade atual, mas representa o seu potencial.

Outro fator a ser destacado é a necessidade de adequar a escala de trabalho à área que se pretende analisar. Embora os estudos em escala 1:50.000 sejam considerados como uma abordagem regional, os dados disponíveis, principalmente relacionados a geomorfologia e aos solos, não eram adequados para representar a área de estudo. Para viabilizar este estudo foi necessário complementar os dados de levantamento secundário com as amostragens e análises de campo.

De qualquer forma, a utilização de modelos é útil ao planejamento ambiental e urbano, visto que é a forma de avaliar áreas extensas de uma forma rápida. Para os locais onde são verificados intensos processos de desequilíbrio ambiental, se deve proceder a um diagnóstico mais específico, em escala maior.

A análise das fragilidades proporciona diretrizes ao planejamento de uso e ocupação, de forma a preservar o equilíbrio ambiental.

\section{Referências Bibliográficas}

AMARAL, R. - Unidades Ecodinâmicas: Análise da fragilidade ambiental do Parque Estadual do Morro do Diabo e entorno, Teodoro Sampaio/SP. 2005. 170f. (Dissertação de Mestrado em Geografia Física) - Departamento de Geografia / FFLCH Universidade de São Paulo. São Paulo.

BERTRAND, G. - Paisagem e Geografia Física Global - Esboço Metodológico. In: Caderno de Ciências da Terra, 13. São Paulo: Instituto de Geografia - Universidade de São Paulo, 1971.
DAEE - SÃO PAULO (ESTADO). Secretaria de Saneamento e Energia - Departamento de águas e Energia Elétrica - disponível em http:/ Lwww.sigrh.sp.gov.br/cgi-bin/bdhm.exe/plu, acesso em 21/03/2003.

IPT - INSTITUTO DE PESQUISAS TECNOLÓGICAS Orientações para o combate à erosão no Estado de São Paulo (Bacia do PeixeParanapanema), Relatório n.o 24.739, São Paulo: DAEE, 1987. 
MONTEIRO, C. A. F. - Geossistemas - a história de uma procura. São Paulo: Contexto, 2000.127 p.

OLIVEIRA, J. B., et. al. Mapa Pedológico do Estado de São Paulo, Rio de Janeiro: Instituto Agronômico de Campinas / Embrapa - Solos, 1999. Mapa color. Escala: 1:500.000.

ROSS, J. L. S. Análise empírica da fragilidade dos ambientes naturais e antropizados. Revista do Departamento de Geografial FFLCH/USP, n.0 8, p. 63-73, 1994.

ROSS, J. L. S. O registro cartográfico dos fatos Geomórficos e a questão da taxonomia do relevo. Revista do Departamento de Geografia/FFLCH/USP, n.0 6, 17-29, 1992.

ROSS, J. L. S., MOROZ, I. C. Mapa Geomorfológico do Estado de São Paulo, São
Paulo: Laboratório de Geomorfologia, DG, FFLCH, USP / Laboratório de Cartografia Geotécnica-Geologia Aplicada - IPT / FAPESP, 1997. Mapa color, v.1 e 2. Escala: 1:500.000.

SMA - SÃO PAULO (ESTADO). Secretaria do Meio Ambiente Zoneamento Econômico e Ecológico do Pontal do Paranapanema. São Paulo, 1999. 170p.

SOTCHAVA, V. B. - Por Uma Teoria de Classificação de Geossistemas da Vida Terrestre. In: Biogeografia no 14. São Paulo: Instituto de Geografia - Universidade de São Paulo, 1978.

TRICART, J. - Ecodinâmica. Rio de Janeiro: FIBGE, Secretaria de Planejamento da Presidência da República, 1977. 97p.

Trabalho enviado em Agosto de 2008

Trabalho aceito em Setembro de 2009 